\title{
PEMBINAAN ANAK PIDANA PADA LEMBAGA PEMASYARAKATAN KELAS II A LABUHAN RUKU
}

\author{
Ricky Utomo Simargolang \\ Politeknik Ilmu Pemasyarakatan Depok, Indonesia \\ Email: Rickyutomo98@gmail.com
}

\begin{tabular}{l}
\hline \multicolumn{1}{c}{ Artikel info } \\
\hline Artikel history: \\
Diterima: 06 November \\
2020 \\
Diterima dalam bentuk \\
revisi: 13 November 2020 \\
Diterima dalam bentuk \\
revisi: 19 November 2020
\end{tabular}

Keywords: Children; Correctional Institutions; Coaching.

\section{Katakunci:}

Anak,Lembaga

Pemasyarakatan, Pembinaan

\begin{abstract}
This study aims to determine the efforts made in coaching children through empirical legal research methods. This research method is a legal research using an empirical approach. "The empirical approach is an approach carried out by conducting direct research to collect all information related to this research, either by interviewing related parties or by careful observation of the research subject. The results of the research and discussion carried out, it can be concluded that the Penitentiary as one of the law enforcement agencies that focuses on the final part of the criminal justice system has a role as an executor of guidance for the prisoners in order to make the prisoners aware of mistakes, improve themselves and do not repeat the crime.
\end{abstract}

\begin{abstract}
Abstrak: Penelitian ini bertujuan untuk mengetahui upayaupaya yang dilakukan dalam melakukan pembinaan terhadap anak melalui metode penelitian hukum empiris. Metode Penelitian ini merupakan penelitian hukum dengan menggunakan pendekatan empiris. "Pendekatan empiris adalah pendekatan yang dilakukan dengan melakukan penelitian secara langsung untuk mengumpulkan semua informasi yang berhubungan dengan penelitian ini, baik dengan wawancara dengan pihak terkait, maupun dengan pengamatan secara seksama terhadap subjek penelitian. hasil penelitian dan pembahasan yang dilakukan maka dapat ditarik kesimpuan bahwa Lembaga Pemasyarakatan sebagai salah satu aparatur penegak hukum yang berfokus pada bagian akhir dari sistem peradilan pidana memiliki peran sebagai pelaksana pembinaan terhadap warga binaan pemasyarakatan yang mana dengan tujuan agar warga binaan meyadari kesalahan, memperbaiki diri dan tidak mengulangi tindak pidana.
\end{abstract}


Koresponden author: Ricky Utomo Simargolang

Email: Rickyutomo98@gmail.com

artikel dengan akses terbuka dibawah lisensi

CC BY SA

2020

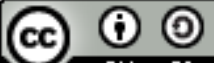

\section{Pendahuluan}

Perkembangan zaman saat ini telah membawa kita kepada perubahan yang tidak dapat terhindarkan, globalisasi seolah menjadi candu yang sangat melekat pada gaya hidup masyarakat, perkembangan globalisasi ini dapat menjadi suatu hal yang positif dan sangat bermanfaat bagi yang mengambil hal-hal positif nya, namun dapat juga menjadi bomerang yang sangat berbahaya dan menghancurkan. Tidak sedikit yang menjadi korban terseret arus globalisasi yang buruk, entah itu pria, wanita, tua, muda bahkan juga telah meracuni tunastunas bangsa kita, anak-anak.

Anak - anak merupakan aset bangsa calon-calon penerus perjuangan bangsa dalam upaya menjadi lebih baik, calon-calon pewaris kekayaan bangsa yang mana kita ketahui begitu kayanya negeri ini mulai dari bahasa, budaya, adat, serta kekayaan alam yang begitu melimpah. Akan menjadi hal yang sangat di sayangkan jika di masa yang akan datang, dimasa sudah saatnya regenerasi dilakukan, dimasa tongkat estafet perjuangan bangsa harus diteruskan, anakanak ini tidak memiliki bekal yang cukup untuk menghadap perkembangan dan perubahan zaman yang begitu luar biasa ini.

Anak-anak yang seharusnya menikmati masa kecilnya dengan bermain, belajar, berkumpul dengan teman-teman sebayanya, mencari pengalaman yang baru, pengalaman bermain yang menyenangkan, mengembangkan kemampuan diri dan potensi mereka di lingkungan sekolah dan lingkungan keluarga, namun harus kandas akibat salah pergaulan. Anak memang merupakan manusia yang masih polos dengan rasa keingintahuan yang sangat tinggi yang tidak menutup kemungkinan akan sangat mudah terpengaruh, ikut-ikutan dan terkontaminasi, entah itu dengan iming iming hal yang menggiurkan atau ajakan dan sebagainya. banyak faktor yang mendasari terjadinya penyimpangan dalam lingkunan anak baik dari kondisi internal keluarga maupun kondisi eksternal lingkungan dan pergaulannya

Banyak bentuk modus-modus yang menjerumuskan anak kedalam buruknya globaslisasi yang menyebabkan anak melanggar norrma-norma dan aturan dan berakibat anak terjerat dalam suatu hukuman pidana,.hingga harus menjalani pidana kurungan dalam waktu tertentu, dalam praktiknya upaya-upaya diversi atau penyelesaian perkara diluar proses peradilan pidana telah di lakukan untuk memastikan pidana kurungan adalah suatu upaya terakhir yang dilakukan dalam melindungi hak anak. Selanjutnya pidana kurungan terhadap anak ini pada umumnya dilakukan di Lembaga Pembinaan Khusus Anak atau LPKA, LPKA merupakan salah satu Unit Pelaksana Teknis (UPT) yang berada di bawah Direktorat jendral Pemasyarakatan Kementerian Hukum dan Hak Asasi Manusia Republik Indonesi. Kegiatan pembinaan dilakukan dengan menggunakan sistem pemasyarakatan,yang mana sistem pemasyarakatan diselenggarakan dalam rangka membentuk Warga Binaan Pemasyarakatan agar menjadi manusia seutuhnya, menyadari kesalahan, memperbaiki diri, dan tidak

dapat aktif berperan dalam pembangunan, dan dapat hidup secara wajar sebagai warga yang baik dan bertanggung jawab (Undang-undang, 1995).

Di Indonesia sendiri Keberadaan Lembaga Pembinaan Khusus Anak (LPKA) dapat dikatakan cukup langka, karena keberadaannya belum menyeluruh di seluruh kota di Indonesia, 
sehingga di beberapa daerah Lembaga Pemasyarakatan menerapkan peran sebagai Lembaga Pembinaan Khusus Anak juga, penerapan perlakuan tentunya akan berbeda dengan narapidana dewasa.

\section{Metode Penelitian}

Penelitian ini merupakan penelitian hukum dengan menggunakan pendekatan empiris. "Pendekatan empiris adalah pendekatan yang dilakukan dengan melakukan penelitian secara langsung untuk mengumpulkan semua informasi yang berhubungan dengan penelitian ini, baik dengan wawancara dengan pihak terkait, maupun dengan pengamatan secara seksama terhadap subjek penelitian (Muhammad, 2004).

\section{Hasil dan Pembahasan}

\section{Peran Lembaga Pemasyarakatan dalam pembinaan anak}

Lembaga pemasyarakatah sebagai salah satu aparatur penegak hukum yang menurut pasal 3 Undang-undang nomor 12 tahun 1995 tentang Pemasyarakatan memiliki fungsi menyiapkan warga binaan pemasyarakatan agar dapat berintegrasi secara sehat dengan masyarakat,sehingga dapat berperan kembali sebagai anggota masyarakat yang bebas dan bertanggung jawab. Lembaga pemasyarakatan sebagai tempat pembinaan warga binaan pemasyarakatan tidak berhak untuk membuat seseorang menjadi pribadi yang lebih buruk dari sebelum seseorang masuk ke dalam lembaga pemasyarakatan, hal ini kemudian selaras dengan tujuan dilakukannya pembinaan terhadap warga binaan pemasyarakatan. Lembaga Pemasyarakatan Kelas IIA Labuhan Ruku pada dasarnyaadalah suatu unit pelaksana teknis pemasyarakatan yang dibuat untuk warga binaan dewasa, namun karena di wilayah hukum tersebut tidak ada Lembaga pemasyarakatan perempuan dan Lembaga Pembinaan Khusus anak maka Lembaga Pemasyarakatan KelasIIA ini menjalankan peran juga sebagai Lapas Perempuan dan LPKA untuk warga binaanperempuan dan anak. Hal ini kemudian mengubah manajemen pelaksanaan kerja pada Lembaga Pemasyarakatan kelas IIA Labuhan ruku, dimana yang awalnya tidak ada narapidana wanita dan anak menjadi ada, sehingga dipisahkanlah kamar hunian dan bloknya.

Anak yang menjalani masa pembinaan di dalam Lembaga pemasyarakatan di tempatkan didalam satu blok atau kamar yang sama dengan anak-anak lainnya, hal ini bertujuan untuk meminimalisir intensitas interaksi dengan orang dewasa yang dapat mempengaruhi psikologi dan karakter anak, Lembaga Pemasyarakatan memiliki peran penting dalam melakukan pembinaan dan pengawasan terhadap proses pembinaan terhadap anak serta menjamin hak-hak anak dapat terpenuhi, dalam kesehariannya petugas mengawasi dan memantau setiap perkembangan anak melalui kegiatan-kegiatan yang di selenggarakan.

\section{Program-program pembinaan dan pembimbingan yang diadakan}

Dari observasi yang di lakukan penetili pada Lembaga Pemasyarakatan kelas IIA Labuhan ruku terdapat beberapa upaya yang dilakukan pihak Lembaga Pemasyarakatan melalui kegiatan atau program pembinaan di Lembaga Pemasyarakatan tersebut, kegiatan ini kemudian dilaksanakan sesuai jadwal yang telah di tentukan. Adapun uraian dari kegiatan tersebut : 
a. Latihan Keterampilan Baris Berbaris (LKBB)

Latiahan Keterampilan Baris Berbaris atau LKBB merupakan sebuah kegiatan yang bertujuan untuk melatih dan membentuk sikap seseorang, dalam kegiatan pembinaan ini anak akan dilatih untuk memiliki sikap dan disiplin dalam gerakan baris berbaris. Kegiatan ini ditangani langsung oleh Subseksi binadik yang mana kegiatan ini dilaksanakan setiap sore setelah melaksanakan kegiatan ibadah sholat ashar.

b. Kerohanian

Proses pembinaan yang dilaksanakan juga mencakup aspek Kerohanian dimana anak tetap melaksanakan kewajiban sebagai warga negara yang beragama, bagi yang muslim tidak hanya ibadah sholat saja namun juga ada mentoring dan baca tulis alquran pada jadwal-jadwal tertentu,hal ini dilakukan karena Pemasyarakatan menyadari bahwa untuk membentuk seorang menjadi lebih baik lagi perlu berbagai metode pendekatan dari berbagai aspek.

c. Kunjungan Keluarga

Anak yang menjalani masa pidana di dalam lembaga pemasyarakatan dan tidak tinggal besama keluarganya, bukan berarti terputus hubungan dan komunikasi dengan keluarganya, anak tetaplah butuh perhatian dan kasih sayang seorang orang tua, Duvall dan Logan ( 1986 ) : Keluarga adalah sekumpulan orang dengan ikatan perkawinan, kelahiran, dan adopsi yang bertujuan untuk menciptakan, mempertahankan budaya, dan meningkatkan perkembangan fisik, mental, emosional, serta sosial dari tiap anggota keluarga. Melalui kunjungan daro keluarga da orang tua anak merasa tidak sendiri menghadapi keadaan yang sedang dihadapai. Motivasiorangtua juga memiliki arti dorongan yang menghasilkan dampak positif untuk kemandirian pada jati diri anak, karena orang motivasi sebagai dorongan, sedangkan orangtua sebagai orang yang pertama dan berhak atas anak untuk menjadikan mereka menjadi diri sendiri. dari observasi yang peneliti lakukan, kunjungan keluarga terhadap anak pada Lembaga pemasyarakatan Kelas IIA Labuhan Ruku menjadi salah satu upaya efektif untuk menekan tingkat stres anak yang sedang menjalani masa pidana di dalam lembaga pemasyarkan, dengan di kunjungi anak akan merasa diperhatikan dan di diperdulikan oleh orang tua dan keluarganya, walaupun dalam kondisinya tidak semua orang tua dapat melakukan kunjungan secara rutin, namun ini tetap menjadi upaya yang efektif.

\section{Kendala dalam Pelaksanaan Program}

Upaya-upaya yang dilakukan untuk mencapai suatu tujuan tentulah melalui prosesproses yang saling berhubungan, istilah kendala dan hambatan merupakan kata yang tidak asing dalam perjalanan mencapai tujuan tersebut, seperti hal nya upaya utuk meningkatkan kompetensi anak pada Lembaga Pemasyarakatan Kelas IIA Labuhan Ruku, peeliti melihat terdapat bebrapa kendala yang mengakibatkan proses pembinaan yang dilaksanakan kurang efektif.

a. Semangat anak untuk mengikuti kegiatan tidak stabil

Program pembinaan yang dilaksanakan oleh anak pada lembaga pemasyarakatan memang diikuti oleh anak yang sedang menjalani masa pidana, anak begitu semangat mengikuti kegiatan namun tidak jarang terlihat bermalas-malasan dan mengeluh yang 
mana ini menjadi penghambat proses pengembangan diri.

b. Terlalu emosional

Kehidupan dalam dunia anak tidak jarang dipengaruhi oleh kondisi psikologi dan kondisi emosional seseorang, peneliti masih menemukan anak yang menjalani masa pidana mengalami perselisihan yang berujung dengan perkelahian, sering kali hal ini di dapati petugas dan langsung di pisahkan, hal ini dilihat penulis sebagai upaya yang dilakukan anak untuk dapat diberikan perhatian dan ingin menunjukan bahwa ia lebih baik di banding yang lainnya, rasa tidak mau kalah dan ingin mendominasi mempengaruhi sisi emosional seorang anak yang kemudian menjadi salah satu penyebab tidak efektifnya program pembinaan.

\section{Kesimpulan}

Dari hasil penelitian dan pembahasan yang dilakukan maka dapat ditarik kesimpuan bahwa Lembaga Pemasyarakatan sebagai salah satu aparatur penegak hukum yang berfokus pada bagian akhir dari sistem peradilan pidana memiliki peran sebagai pelaksana pembinaan terhadap warga binaan pemasyarakatan yang mana dengan tujuan agar warga binaan meyadari kesalahan, memperbaiki diri dan tidak mengulangi tindak pidana. Upaya yang dilakukan oleh pihak Lembaga Pemasyarakatan Kelas IIA Labuhan Ruku dalam melakukan pembinaan terhadap anak pidna adalah melalui kegiatan latihan baris-berbaris, kegiatan kerohanian dan Kunjungan Keluarga. Namun dalam upaya menjadi lebih baik terdapat beberapa kendala dalam mencapai tujuan tersebut yaitu semangat anak yang belum stabil dalam kegiatan dan masih terlalu emosionalnya anak dalam bertingkah laku. 


\section{Bibliografi}

Muhammad, A. (2004). Hukum Dan Penelitian Hukum (Bandung: PT. Citra Aditya Bakti, 2004). Abdulkadir Muhammad.

Undang-undang. (1995). Undang-Undang nomor 12 tahun 1995 Tentang Pemasyarakatan. www.bphn.go.id

Anak Agung Sri Sanjiwani, Afif Kurniawan, I. P. W. B. (2020). Pelatihan strategi koping pada narapidana remaja di lembaga pemasyarakatan. Jurnal psikologi ilmiah, 12(1), 8292. https://doi.org/10.15294/intuisi.v12i1.22275

Anggara, B. (2017). Pemenuhan Hak-Hak Pendidikan Keagamaan Islam Anak Binaan Di Lembaga Pemasyarakatan Pakjo Palembang. Tadrib: Jurnal Pendidikan Agama Islam, 3(1), 162. https://doi.org/10.19109/tadrib.v3i1.1389

Bambang Sukoco. (2016). Pendekatan Restoratif Justice Sebagai Upaya Penyelesaian Cybercrime Dengan Pelaku Anak (Studi Kasus)

Penyelesaian Tindak Pidana Anak Usia Sekolah). Jurnal Law and Justice, 1(1), 54-64. https://doi.org/10.23917/laj.v1i1.2859

Biafri, V. S. (2019). Pembinaan Teroris Anak Di Lembaga Pembinaan Khusus Anak Klas I Di Tangerang. Sosio Konsepsia, 8(02), 14-26. https://doi.org/10.33007/ska.v8i2.1450

Chusniatun. (2018). Sistem Perlindungan Hukum Bagi Anak di Lembaga Pemasyarakatan Dalam Perspektif Konvensi Internasional Hak-Hak Anak. 30(01), 103-132.

Undang-Undang nomor 12 tahun 1995 Tentang Pemasyarakatan, (1995). www.bphn.go.id

Irawan, R. (2018). Konsep Diri Warga Lembaga Pemasyarakatan. SCHOULID: Indonesian Journal of School Counseling, 3(2), 41-45. https://doi.org/10.23916/08423011

Ismawati, S. (2013). Upaya Perlindungan Hak Asasi Manusia Dalam Pembinaan Narapidana Anak (Studi Di Lembaga Pemasyarakatan Klas Ii B Anak Pontianak). Masalah-Masalah Hukum, 42(3), 405-415. https://doi.org/10.14710/mmh.42.3.2013.405-415

Kahesti, Y. Z. (2018). Pemenuhan Hak Anak di Bidang Pendidikan pada Lembaga Pemasyarakatan Kelas IIA Kota Balikpapan. Jurnal Magister Hukum Udayana(Udayana Master Law Journal), 7(3), 343-359.https://doi.org/10.24843/JMHU.2018.v07.i03.p06

Makhmudah, S. (2018). Penguatan peran keluarga dalam pendidikan Anak. Martabat: Jurnal Perempuan dan Anak, 2(2), 269-286. https://doi.org/http://dx.doi.org/10.21274/martabat.2018.2.2.269-286

Marsaid. (2015). Perlindungan hukum anak pidana dalam perspektif.

Maqasid asy-syari'ah (Studi Kasus Penanganan Anak Pidana di Lembaga PemasyarakatanJambi). Nurani,15(2),1-26. https://doi.org/10.19109/nurani.v15i2.280

Prabowo, B. B. (2015). Pemenuhan Hak Menyampaikan Keluhan Bagi Anak Di Lembaga Pemasyarakatan Anak Blitar. Arena Hukum, 8(2), 280-299. https://doi.org/10.21776/ub.arenahukum.2015.00802.8 
Ricky Utomo Simargolang

Siddiq, S. A. (2015). Pemenuhan Hak Narapidana Anak dalam Mendapatkan Pendidikan dan Pelatihan. Pandecta: Research Law Journal, 10(1). https://doi.org/10.15294/pandecta.v10i1.4195

Utami, P. N. (2018). Pencegahan Kekerasan Terhadap Anak dalam Perspektif Hak Atas Rasa Aman di Nusa Tenggara Barat. Jurnal HAM, 9(1), 1-17. https://doi.org/http://dx.doi.org/10.30641/ham.2018.9.1-17 